\title{
Modyfikacja znormalizowanej metody prowadzenia prób ciśnieniowych celem jej wykorzystania do badania szczelności gazociągów z poliamidu PA 12
}

\author{
Modification of the standardized pressure test method for use in leakage testing of gas \\ pipelines made of PA-12 polyamide
}

\author{
Piotr Szewczyk \\ Instytut Nafty i Gazu - Państwowy Instytut Badawczy
}

\begin{abstract}
STRESZCZENIE: Gazociągi przed oddaniem do eksploatacji poddawane są ciśnieniowym próbom szczelności i wytrzymałości. W przypadku gazociągów z tworzyw sztucznych wykonuje się próbę łączoną szczelności i wytrzymałości przy ciśnieniu 1,5 × MOP. W Polsce, zgodnie z obowiązującymi przepisami, tworzywem sztucznym, z którego można budować gazociągi, jest polietylen. Za granicą gazociągi budowane są również z innego materiału, jakim jest poliamid PA 12. Systemy rurowe z PA 12 wykorzystywane są do przesyłania gazu pod ciśnieniem 1,6 MPa. Zarówno gazociągi z polietylenu, jak i z poliamidu, po obciążeniu ich ciśnieniem wewnętrznym wraz z upływem czasu będą podlegały odkształceniom, co nazywane jest zjawiskiem pełzania materiału. Powoduje to, że w ciśnieniowych próbach szczelności gazociągów z tworzyw termoplastycznych, jakimi są polietylen i poliamid, wymagane jest uwzględnienie tego zjawiska. Ze względu na odmienne właściwości polietylenu i poliamidu wielkość odkształceń w jednostce czasu będzie różna i dlatego procedury prób, które stosowane są w przypadku gazociągów z polietylenu, nie mogą być wprost wykorzystane do prób w przypadku gazociągów z poliamidu. Przykładem takiej procedury jest ta opisana w punkcie A.27 normy PN-EN 805:2002. Jest ona stosowana głównie do badania szczelności wodociągów z polietylenu i wykorzystanie jej do badania szczelności gazociągów z poliamidu PA 12 o MOP =1,6 MPa wymaga zmiany warunków próby. W artykule przedstawiono koncepcję modyfikacji parametrów metody hydrostatycznej uwzględniającą odmienne właściwości rur z PA 12 w stosunku do rur z polietylenu. Szczególną uwagę zwrócono na większą wartość modułu Younga i związaną z nim sztywność obwodową rur z poliamidu PA 12 w porównaniu z rurami z polietylenu. Aby uzyskać odpowiednie odkształcenie rury wynikające ze zjawiska pełzania materiału, doświadczalnie wydłużano czas utrzymywania próbki pod ciśnieniem przed przystąpieniem do próby właściwej. Po ustaleniu wymaganych warunków próby, które wyznaczono dla układu szczelnego, przeprowadzono próby z symulowanymi nieszczelnościami. Uzyskane wyniki badań na próbkach szczelnych oraz z symulowaną nieszczelnością potwierdziły możliwość wykorzystania zmodyfikowanej metody do badania szczelności gazociągów z poliamidu PA 12 o MOP =1,6 MPa.
\end{abstract}

Słowa kluczowe: gazociąg, próba ciśnieniowa, rury z poliamidu PA 12.

ABSTRACT: Before being put into operation, gas pipelines are subjected to leakage and strength pressure testing. In the case of plastic gas pipelines, a combined leakage and strength test is performed at a pressure of $1.5 \times \mathrm{MOP}$. In Poland, in accordance with the applicable regulations, the plastic material from which gas pipelines can now be built is polyethylene. In other countries gas pipelines are also built of another material, which is PA12 polyamide. Piping systems made of this material are used to transmit gas at a pressure of 1.6 MPa. Both polyethylene and polyamide gas pipelines, after loading them with internal pressure, will undergo deformation with time, which is called the material creep phenomenon. As a result, in pressure leakage tests of gas pipelines made of thermoplastics, such as polyethylene and polyamide, it is necessary to take this phenomenon into account. Due to the different properties of polyethylene and polyamide, the amount of deformation per unit time will be different, and therefore the test procedures that are used for polyethylene gas pipelines cannot be directly used for testing polyamide gas pipelines. An example of such a procedure is the one described in point A.27 of PN-EN 805: 2002. It is mainly used for leakage testing of polyethylene water pipelines and its application for leakage testing of PA12 polyamide gas pipelines with a MOP of 1.6 MPa requires changes in the test conditions. The article presents the concept of modifying the parameters of the hydrostatic method, taking into account the different properties of PA12 pipes compared to polyethylene pipes. Particular attention was paid to the higher value of Young's modulus and the related ring stiffness of PA12 polyamide pipes compared to polyethylene pipes. In order to obtain the appropriate deformation of the pipe resulting from the material creep, the time of holding the sample under pressure was experimentally extended before starting the actual test. After establishing the required test conditions for the sealed system, tests with simulated leaks were carried out. The obtained results of tests on airtight samples and with simulated leakage confirmed the possibility of using the modified method to test the tightness of PA 12 polyamide gas pipelines with a MOP of 1.6 MPa.

Key words: gas pipeline, pressure testing, PA 12 polyamide pipes.

Autor do korespondencji: P. Szewczyk, e-mail: piotr.szewczyk@inig.pl

Artykuł nadesłano do Redakcji: 17.02.2021 r. Zatwierdzono do druku: 27.05.2021 r. 


\section{Wprowadzenie}

Ze względu na odmienne właściwości tworzyw sztucznych badania szczelności wykonanych z nich rurociągów powinny być prowadzone zgodnie z wymaganiami uwzględniającymi charakterystyczne cechy określonego rozwiązania materiałowego (Kupraszewicz, 2008) jak również konstrukcji rur, np. wielowarstwowych czy też kompozytowych, które charakteryzują się wysoką odpornością na ciśnienie wewnętrzne, ograniczonym pełzaniem, większą sztywnością obwodową oraz mniejszym współczynnikiem rozszerzalności liniowej (Klupa, 2010). Poddanie rury z tworzywa termoplastycznego działaniu ciśnienia wewnętrznego będzie powodowało jej odkształcenie. Zjawisko to nazywane jest pełzaniem materiału. Wraz z upływem czasu poziom odkształcenia będzie malał. Zmniejszał się będzie również poziom naprężeń w ściance rury, co nazywane jest relaksacją naprężeń (Janson, 1996; Bolt i Suligowski, 2007). W celu prawidłowej realizacji ciśnieniowej próby szczelności rurociągów z poliamidu PA 12 niezbędne jest uwzględnienie odkształceń występujących pod wpływem działania ciśnienia próby, co wymagane jest również przez normę PN-EN 12327:2013, określającą wymagania funkcjonalne prób ciśnieniowych dla infrastruktury gazowej. W ramach prowadzonej działalności statutowej w INiG - PIB w 2017 r. zrealizowano pracę (Szewczyk, 2017), której celem była weryfikacja dostępnych procedur prowadzenia prób szczelności rurociągów wykonanych z tworzyw sztucznych o maksymalnym ciśnieniu roboczym $\mathrm{MOP}=1,6 \mathrm{MPa}$. W wyniku przeprowadzonej analizy jako metodę uwzględniającą zjawisko pełzania materiału do dalszych badań wybrano metodę opisaną w punkcie A.27 normy PN-EN 805:2002. Metoda ta jest wykorzystywana do sprawdzania szczelności wodociągów z polietylenu o ciśnieniu nominalnym PN16. Na podstawie tej metody przeprowadzono badania szczelności próbek rur z PA 12. Uzyskane wyniki wskazywały na konieczność dostosowania jej parametrów do właściwości rur z poliamidu PA 12.

\section{Opracowanie koncepcji modyfikacji metody badania szczelności}

Aby dokonać zmian właściwych parametrów próby konieczne jest poddanie analizie jej poszczególnych etapów. Procedura obejmuje trzy etapy:

- próbę wstępną;

- zintegrowaną próbę spadku ciśnienia;

- próbę główną.

Próba wstępna składa się natomiast z dwóch części. W pierwszej kolejności rurociąg utrzymywany jest pod stałym ciśnieniem próby (STP) wynoszącym 1,5 MOP, a ewentualne spadki ciśnienia, wynikające z odkształcania się rury spowodowanego pełzaniem materiału, rekompensowane są przez dopompowywanie wody. W tym czasie powinno nastąpić odkształcenie rurociągu do takiego stopnia, który w etapie próby głównej, po zmniejszeniu ciśnienia przez gwałtowne upuszczenie wody, pozwoli na wystąpienie skurczu rury powodującego wymagany wzrost ciśnienia. Zgodnie z normą PN-EN 805:2002 wymagane odkształcenie rury powinno nastąpić w czasie 30 min utrzymywania jej pod ciśnieniem próby. Dla takiej wartości czasu przeprowadzone badania (Szewczyk, 2017) na szczelnych próbkach kończyły się wynikiem negatywnym wskazującym na potencjalną nieszczelność. Mogło to być spowodowane tym, że w założonym czasie nie nastąpiło wystarczające odkształcenie rur, co z kolei mogło wynikać z tego, że rury z poliamidu PA 12 w porównaniu do rur PE posiadają większą wartość modułu Younga (Mason et al., 2017) i związaną z nim sztywność obwodową. Aby uzyskać odpowiednie odkształcenie rury, wynikające ze zjawiska pełzania materiału, może być więc konieczne wydłużenie czasu utrzymywania próbki pod ciśnieniem próby.

Druga część próby wstępnej ogranicza się jedynie do obserwacji spadku ciśnienia w czasie 60 min, kiedy próbka odłączona jest od źródła ciśnienia. W tym czasie spadek ciśnienia nie powinien być większy niż 30\% wartości ciśnienia próby. Podczas realizowanych prób (Szewczyk, 2017) nie było przypadku, aby to kryterium nie zostało spełnione, dlatego też nie ma potrzeby rozważania ustalenia nowego kryterium.

Drugi oraz trzeci etap próby należy poddać wspólnej analizie. W etapie drugim poprzez gwałtowne obniżenie ciśnienia powinno nastąpić przerwanie pełzania materiału rury, a w etapie trzecim w wyniku skurczu rury powinien nastąpić wzrost ciśnienia. Wzrost ten powinien być obserwowalny w czasie 30 min próby głównej. Wyniki prób (Szewczyk, 2017) wskazywały na właściwy początkowy wzrost ciśnienia, jednak po około 15 min następowała jego stabilizacja, co nie było wystarczające do zakończenia próby z wynikiem pozytywnym. Ponieważ nie zaobserwowano jednocześnie wyraźnego spadku ciśnienia, zgodnie z procedurą wg normy PN-EN 805:2002 próby kontynuowano przez kolejne $60 \mathrm{~min}$. Ostatecznie jednak uzyskane wyniki nie spełniły kryterium dopuszczalnego spadku ciśnienia próby głównej, wynoszącego $25 \mathrm{kPa}$. Poddając analizie te dwa etapy próby, należy rozważyć, czy spełnienie ustalonego kryterium nie będzie zależało od stopnia skurczu rury wynikającego z obniżenia ciśnienia w zintegrowanej próbie spadku ciśnienia. Większa wartość skurczu mogłaby powodować większy wzrost ciśnienia, który mógłby być wystarczający do spełnienia ustalonego kryterium. Aby uzyskać większy stopień skurczu rury, należałoby wyznaczyć doświadczalnie, o ile należy zwiększyć spadek ciśnienia $\Delta$ p w stosunku do wartości określonej w normie PN-EN 805:2002, wynoszącej 
od 10\% do 15\% wartości ciśnienia próby. Po ustaleniu optymalnej wartości $\Delta$ p i w dalszym ciągu negatywnym wyniku próby należałoby rozważyć ustalenie nowego kryterium dla próby głównej.

Reasumując modyfikację znormalizowanej metody prowadzenia prób szczelności wg normy PN-EN 805:2002, należy rozpocząć od ustalenia czasu utrzymywania próbki pod ciśnieniem przez dopompowywanie wody w celu uzyskania odpowiedniego odkształcenia rury. Jeżeli pomimo wydłużonego czasu wyniki prób będą negatywne, należy wyznaczyć doświadczalnie wartość $\Delta p$ zintegrowanej próby spadku ciśnienia dla uzyskania optymalnego skurczu rury, który powodowałby wzrost ciśnienia w próbie głównej pozwalający na spełnienie kryterium dopuszczalnego spadku ciśnienia o $25 \mathrm{kPa}$.

W przypadku gdy ustalone nowe warunki prowadzenia próby, tj. wydłużony czas stabilizacji zjawiska pełzania oraz zwiększona wartość $\Delta p$ zintegrowanej próby spadku ciśnienia, nie pozwolą na otrzymanie pozytywnego wyniku próby, należało będzie ustalić nowe kryterium próby głównej.

\section{Badania modelowe}

Badania modelowe przeprowadzone zostały na próbkach wykonanych z rur o średnicach nominalnych $\mathrm{d}_{\mathrm{n}} 110$ i 160 . Dla każdej z próbek przeprowadzono po sześć prób według procedury opisanej w normie PN-EN 805:2002. Badania wykonywano w temperaturze $23 \pm 2^{\circ} \mathrm{C}$. Zgodnie z opracowaną koncepcją próby różniły się czasem utrzymywania badanych próbek pod stałym ciśnieniem poprzez dopompowywanie wody. Pierwsze badanie wykonano, utrzymując próbki pod ciśnieniem próby przez $60 \mathrm{~min}$, a kolejne przez $120 \mathrm{~min}, 180 \mathrm{~min}$, $240 \mathrm{~min}, 300 \mathrm{~min}$ i $360 \mathrm{~min}$. Podczas prób wyniki oceniano na podstawie pięciu kryteriów.

Kryterium I - brak przecieku podczas próby wstępnej (ocena wizualna). We wszystkich 12 próbach kryterium to zostało spełnione.

Kryterium II - spadek ciśnienia $\left(\Delta p_{(\mathrm{I})}\right)$ po czasie $60 \mathrm{~min}$ od odłączenia układu utrzymującego ciśnienie nie powinien być większy niż 30\% wartości ciśnienia próby: $\Delta p_{(\mathrm{I})} \leq 30 \%$ STP. Również to kryterium we wszystkich 12 przypadkach zostało spełnione. Zmieniały się jednak wartości $\Delta p_{(\mathrm{I})}$ w zależności od czasu, w jakim próbki utrzymywane były pod ciśnieniem przez dopompowywanie, co dla próbki o średnicy $\mathrm{d}_{\mathrm{n}} 110$ zobrazowano na rysunku 1.

Wraz z wydłużaniem czasu utrzymywania próbek pod ciśnieniem przez dopompowywanie - spadek ciśnienia $\Delta \mathrm{p}_{(\mathrm{I})}$ w czasie próby wstępnej był coraz mniejszy. Wynikało to $\mathrm{z}$ tego, że wraz z wydłużaniem czasu dopompowywania następował wzrost odkształceń rury powodujący, że w drugiej części próby pełzanie materiału rury również się zmniejszało.
Kryterium III - objętość upuszczonej wody podczas zintegrowanej próby spadku ciśnienia $(\Delta V)$ powinna być nie większa niż wartość dopuszczalna $\left(\Delta V_{\max }\right)$ obliczona z uwzględnieniem rzeczywistych wymiarów geometrycznych badanego rurociągu, współczynnika sprężystości objętościowej wody oraz modułu sprężystości ścianki przewodu w kierunku obwodowym: $\Delta V \leq \Delta V_{\max }$. We wszystkich przypadkach kryterium to było spełnione.

Kryterium IV - kryterium próby głównej trwającej 30 min: - wzrost ciśnienia w czasie próby - wynik pozytywny;

- spadek ciśnienia - wynik negatywny, świadczący o przecieku.

W przypadkach wątpliwych dopuszczalne jest wydłużenie próby do $90 \mathrm{~min}$.

We wszystkich przypadkach w czasie 30 min próby głównej zaobserwowano początkowy wzrost ciśnienia, po czym następowała jego stabilizacja, a w końcowej części spadek ciśnienia, który w jednej próbie wynosił 0,2 bar, w ośmiu przypadkach: 0,1 bar. Tylko w trzech próbach wykonanych na próbce o średnicy $\mathrm{d}_{\mathrm{n}} 110$ nie zaobserwowano spadku ciśnienia. Były to próby, dla których czas dopompowywania wynosił $120 \mathrm{~min}, 180 \mathrm{~min}$, 240 min. Takie wyniki nie mogły zostać uznane za pozytywne. Ponieważ standardowa znormalizowana metoda badania szczelności dopuszczała wydłużenie czasu trwania próby głównej do $90 \mathrm{~min}$, podczas badań modelowych postąpiono w ten sam sposób i do końcowej oceny prób zastosowano kryterium V.

Kryterium V - od wartości maksymalnej ciśnienia, jaka wystąpiła w czasie trwania próby głównej, spadek ciśnienia $\left(\Delta \mathrm{p}_{\text {(II) }}\right)$ nie może być większy niż $25 \mathrm{kPa}\left(0,25\right.$ bar): $\Delta p_{\text {(II) }} \leq 0,25$ bar.

Dla próbki o średnicy nominalnej $\mathrm{d}_{\mathrm{n}} 110$ kryterium to nie zostało spełnione tylko w przypadku, gdy czas dopompowywania wynosił $60 \mathrm{~min}$. W pozostałych próbach kryterium zostało spełnione i wyniki prób można było uznać za pozytywne, przy czym dla prób, w których czas dopompowywania wynosił $120 \mathrm{~min}$ i $180 \mathrm{~min}$, spadek ciśnienia miał wartość 0,2 bar. W przypadku czasów dopompowywania równych

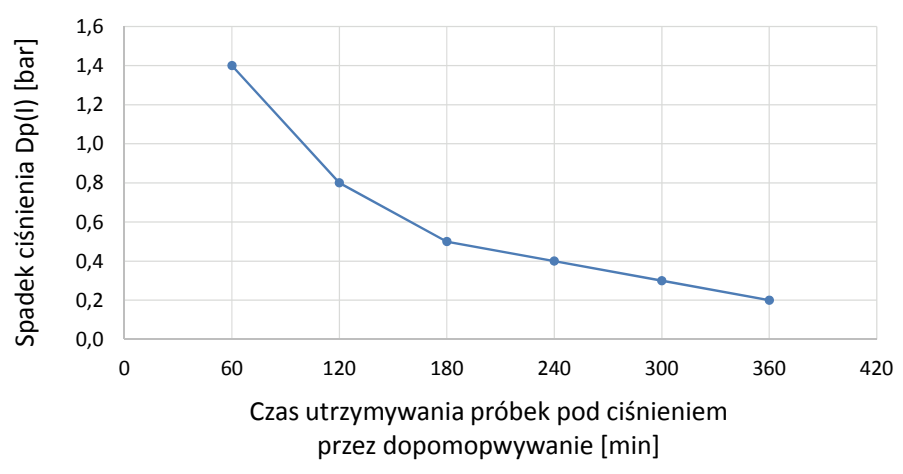

Rys. 1. Spadek ciśnienia $\Delta p_{\text {(I) }}$ w zależności od czasu, w jakim próbki dn 110 były utrzymywane pod ciśnieniem przez dopompowywanie

Fig. 1. Pressure drop $\Delta p_{\text {(I) }}$ versus time during which the dn 110 samples were held under pressure by pumping 
240 min, 300 min i 360 min spadki ciśnienia wynosiły tylko 0,1 bar. Dla próbki o średnicy nominalnej $\mathrm{d}_{\mathrm{n}} 160$ kryterium $\mathrm{V}$ nie zostało spełnione w próbach, w których czas dopompowywania wynosił $60 \mathrm{~min}$ i $120 \mathrm{~min}$. W próbie z czasem dopompowywania wynoszącym 180 min spadek ciśnienia był równy 0,2 bar. W przypadku pozostałych prób, z czasem dopompowywania $240 \mathrm{~min}, 300 \mathrm{~min}$ i $360 \mathrm{~min}$, spadki ciśnienia wynosiły 0,1 bar.

Na podstawie uzyskanych wyników można stwierdzić, że pozytywny wynik badania szczelności dla próbek o średnicach $\mathrm{d}_{\mathrm{n}} 110$ i 160 można uzyskać po czasie dopompowywania równym $180 \mathrm{~min}$. W obu przypadkach spadek ciśnienia $\Delta p_{\text {(II) }}$ był mniejszy tylko o 0,05 bar od wartości dopuszczalnej 0,25 bar. W celu stwierdzenia, czy czas dopompowywania równy 180 min będzie wystarczający przy badaniu szczelności gazociągów z PA 12, analizie poddano wyniki pomiarów odkształceń rur w charakterystycznych punktach próby szczelności, które graficznie przedstawiono na rysunkach 2 i 3.

Punkt 0 oznacza próbki rur bez ciśnienia, 1 - osiągnięcie ciśnienia próby, 2 - zakończenie dopompowywania, 3 - zakończenie próby wstępnej, 5 - zakończenie zintegrowanej próby spadku ciśnienia, 6 i 7 - próbę główną (30 min), 8 - zakończenie próby głównej (90 min).

Jak wynika z przedstawionych wykresów, wraz z wydłużaniem czasu utrzymywania próbek pod ciśnieniem przez dopompowywanie wzrastało odkształcenie rur w kierunku obwodowym, powodując zwiększanie się średnicy zewnętrznej. Jednakową wielkość odkształcenia można zauważyć w przypadku prób, w których czas dopompowywania wynosił $240 \mathrm{~min}, 300 \mathrm{~min}$ i $360 \mathrm{~min}$.

Zaobserwowana stabilizacja odkształcania się rur znajduje również odzwierciedlenie $\mathrm{w}$ wartościach spadków ciśnienia $\Delta p_{\text {(II) }}$, które dla prób z czasem dopompowywania wynoszącym $240 \mathrm{~min}, 300 \mathrm{~min}$ i $360 \mathrm{~min}$ były jednakowe, a zarazem najmniejsze i wynosiły 0,1 bar.

Dlatego też pomimo spełnienia kryterium próby głównej dla prób z utrzymywaniem ciśnienia przez dopompowywanie w czasie $180 \mathrm{~min}$ - za minimalny czas dopompowywania pozwalający na uzyskanie pozytywnego wyniku badania szczelnej próbki uznano $240 \mathrm{~min}$. Z uwagi na to, że dla prób, w których czas dopompowywania wynosił 300 min i 360 min otrzymano identyczne wyniki odkształcenia rur w czasie dopompowywania oraz identyczne spadki ciśnienia $\Delta \mathrm{p}_{\text {(II) }}$, przyjęto, że wystarczającym czasem powodującym odkształcenie rury w etapie próby wstępnej będzie $240 \mathrm{~min}$.

W zmodyfikowanej metodzie prowadzenia prób szczelności można natomiast pominąć kryterium IV, gdyż w żadnym $z$ przypadków nie zostało ono spełnione, a procedura i tak dopuszczała wydłużenie próby do 90 min i ocenę według kryterium $\mathrm{V}$.

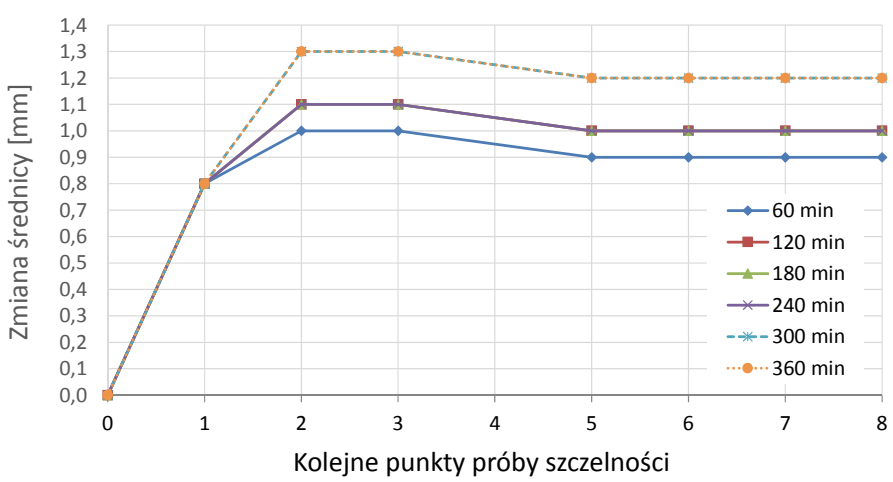

Rys. 2. Zmiany średnicy rur $d_{n} 110$ podczas prób szczelności przy różnych czasach dopompowywania

Fig. 2. Changes in the diameter of $d_{n} 110$ pipes during leakage tests at different pumping times

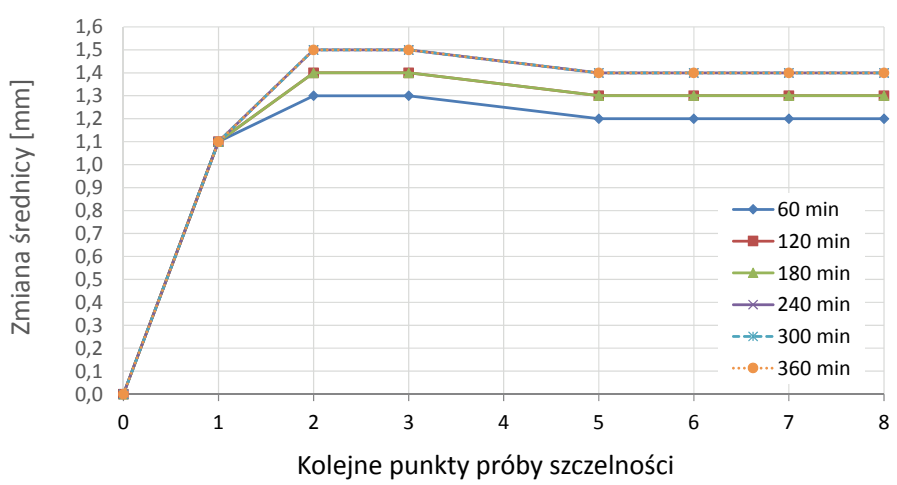

Rys. 3. Zmiany średnicy rur $d_{n} 160$ podczas prób szczelności przy różnych czasach dopompowywania

Fig. 3. Changes in the diameter of $d_{n} 160$ pipes during leakage tests at different pumping times

W celu ustalenia warunków próby szczelności, wszystkie opisane badania wykonywano na próbkach szczelnych. Kolejnym etapem było sprawdzenie, czy przy ustalonych założeniach możliwe będzie wykrycie nieszczelności. W związku z tym przeprowadzono próby z symulowanymi nieszczelnościami. Dla próbki o średnicy $\mathrm{d}_{\mathrm{n}} 110$ nieszczelność wynosiła średnio $140 \mathrm{ml} / \mathrm{h}$, a dla próbki $\mathrm{d}_{\mathrm{n}} 160$ - średnio $30 \mathrm{ml} / \mathrm{h}$. Zarówno w jednym, jak i w drugim przypadku nieszczelności zostały wykryte w fazie próby głównej, gdzie spadki ciśnienia $\Delta p_{\text {(II) }}$ wynosiły odpowiednio 4,4 bar i 0,6 bar.

Opierając się na uzyskanych wynikach, opracowano modyfikację znormalizowanej metody badania szczelności gazociągów z poliamidu PA 12. Wszystkie realizowane badania wykonywane były przy założeniu, że ciśnienie próby powinno wynosić 1,5 MOP, tj. 24 bar. Podczas prób szczelności gazociągów z PA 12, podobnie jak w przypadku gazociągów z polietylenu, należy jednak pamiętać o konieczności uwzględnienia wartości ciśnienia krytycznego szybkiej propagacji pęknięć, która jest wymagana do określenia warunków wykonywania próby (Wróblewska, 2013; PN-EN 12327:2013). Zgodnie z normą ISO 16486-6:2012 przy wykonywaniu prób szczel- 
ności w temperaturze poniżej $0^{\circ} \mathrm{C}$ może być konieczne obniżenie wartości ciśnienia próby.

\section{Zmodyfikowana hydrostatyczna metoda sprawdzania szczelności gazociągów z poliamidu PA 12}

\section{Próba wstępna}

Wykonanie próby wstępnej jest warunkiem przeprowadzenia próby głównej. W czasie trwania próby wstępnej następuje ustalenie warunków wstępnych dotyczących zmian objętości rurociągu w zależności od ciśnienia, czasu i temperatury.

Po odpowietrzeniu rurociągu należy obniżyć ciśnienie do ciśnienia atmosferycznego i pozostawić na okres minimum $60 \mathrm{~min}$. W tym czasie następuje relaksacja naprężeń wywołanych przez ciśnienie. Trzeba zwracać uwagę, aby nie dopuścić do zapowietrzenia badanego odcinka rurociągu.

Po zakończeniu relaksacji należy zwiększać ciśnienie W sposób ciągły (nie krócej niż 10 min) do wartości ciśnienia próbnego i utrzymywać je w ciągu 240 min przez pompowanie ciągłe lub z krótkimi przerwami. W tym czasie trzeba przeprowadzić kontrolę wizualną w celu stwierdzenia rzeczywistych przecieków (w odkrytych miejscach połączeń rurociągu).

Kryterium I: brak przecieku (ocena wizualna)

Następnie należy pozostawić rurociąg pod ciśnieniem na okres 60 min bez pompowania. W tym czasie gazociąg może się odkształcać wskutek pełzania lepkosprężystego, co będzie powodowało spadek ciśnienia. Stabilizacja ciśnienia oznaczać będzie ograniczenie pełzania materiału rury. Wówczas należy odczytać ciśnienie pod koniec tego okresu.

Jeżeli ciśnienie spadło o więcej niż 30\% ciśnienia próby (STP), należy przerwać próbę wstępną i obniżyć ciśnienie do ciśnienia atmosferycznego, a następnie przeanalizować warunki badania (np. wpływ temperatury). Ponowne rozpoczęcie procedury próby wstępnej można rozpocząć tylko po zakończeniu okresu relaksacji, trwającego minimum 60 min.

Kryterium II: $\Delta p_{(\mathrm{I})} \leq 30 \% \times \mathrm{STP}$

Spełnienie kryteriów I i II próby wstępnej jest warunkiem przystąpienia do kolejnych etapów próby.

\section{Zintegrowana próba spadku ciśnienia}

Głównym celem zintegrowanej próby spadku ciśnienia jest przerwanie pełzania materiału rury spowodowanego naprężeniami wywołanymi przez ciśnienie próby.

Zintegrowana próba spadku ciśnienia pozwala także ocenić, czy objętość powietrza pozostałego w rurociągu będzie odpowiednio niska, co jest warunkiem przeprowadzenia próby głównej.

Po zakończeniu próby wstępnej należy szybko obniżyć zmierzone na jej końcu ciśnienie, odprowadzając z badanego rurociągu wodę do momentu osiągnięcia $p$ równego od $10 \%$ do $15 \%$ wartości ciśnienia próby.

Należy zmierzyć objętość usuniętej wody $\Delta V$, obliczyć dopuszczalny ubytek wody $\Delta V_{\max }$ i sprawdzić, czy wartość $\Delta V$ nie jest większa niż $\Delta V_{\max }$ :

$$
\Delta V_{\max }=1,2 \cdot V \cdot \Delta p\left(\frac{1}{E_{w}}+\frac{D}{e \cdot E_{R}}\right)
$$

gdzie:

$\Delta V_{\max }-$ dopuszczalny ubytek wody $\left[\mathrm{dm}^{3}\right]$,

$V$ - objętość badanego odcinka gazociągu $\left[\mathrm{dm}^{3}\right]$,

$\Delta p$ - zmierzony spadek ciśnienia [kPa],

$E_{w}$ - współczynnik sprężystości objętościowej wody [kPa],

$D$ - wewnętrzna średnica przewodu [m],

$e$ - grubość ścianki przewodu [m],

$E_{R}$ - moduł sprężystości ścianki przewodu w kierunku obwodowym $[\mathrm{kPa}]$,

1,2 - współczynnik korekcyjny (np. ze względu na zawartość powietrza) w czasie przeprowadzania głównej próby ciśnieniowej.

Dla rur z poliamidu PA 12, zgodnie z danymi producenta surowca, wartość $E_{R}[\mathrm{kPa}]$ można przyjąć jako $1140 \times 10^{3}$.

Kryterium III: $\Delta V \leq \Delta V_{\max }$

Jeżeli $\Delta V$ jest większe niż $\Delta V_{\max }$, należy przerwać procedurę próby i ponownie odpowietrzyć rurociąg.

\section{Próba glówna}

Gwałtowne zmniejszenie ciśnienia w zintegrowanej próbie spadku ciśnienia będzie powodować skurcz rurociągu, który podczas próby głównej powinien powodować początkowy wzrost ciśnienia. Próba główna powinna trwać 90 min. W tym czasie powinna następować stabilizacja ciśnienia, a ewentualny jego spadek nie powinien być większy niż 0,25 bar od wartości maksymalnej, jaka wystąpiła w czasie $90 \mathrm{~min}$.

$\underline{\text { Kryterium IV: } \Delta p_{(\text {II) }} \leq 0,25 \mathrm{bar}}$

Jeżeli spadek ciśnienia jest większy niż 0,25 bar, wynik próby jest negatywny.

Po zlokalizowaniu i usunięciu nieszczelności ponowne wykonanie próby głównej jest możliwe pod warunkiem przeprowadzenia uprzednio całej procedury próby wstępnej i próby zintegrowanego spadku ciśnienia. Ogólny przebieg zmian ciśnienia podczas zmodyfikowanej próby szczelności gazociągów z PA 12 przedstawiono na rysunku 4. 


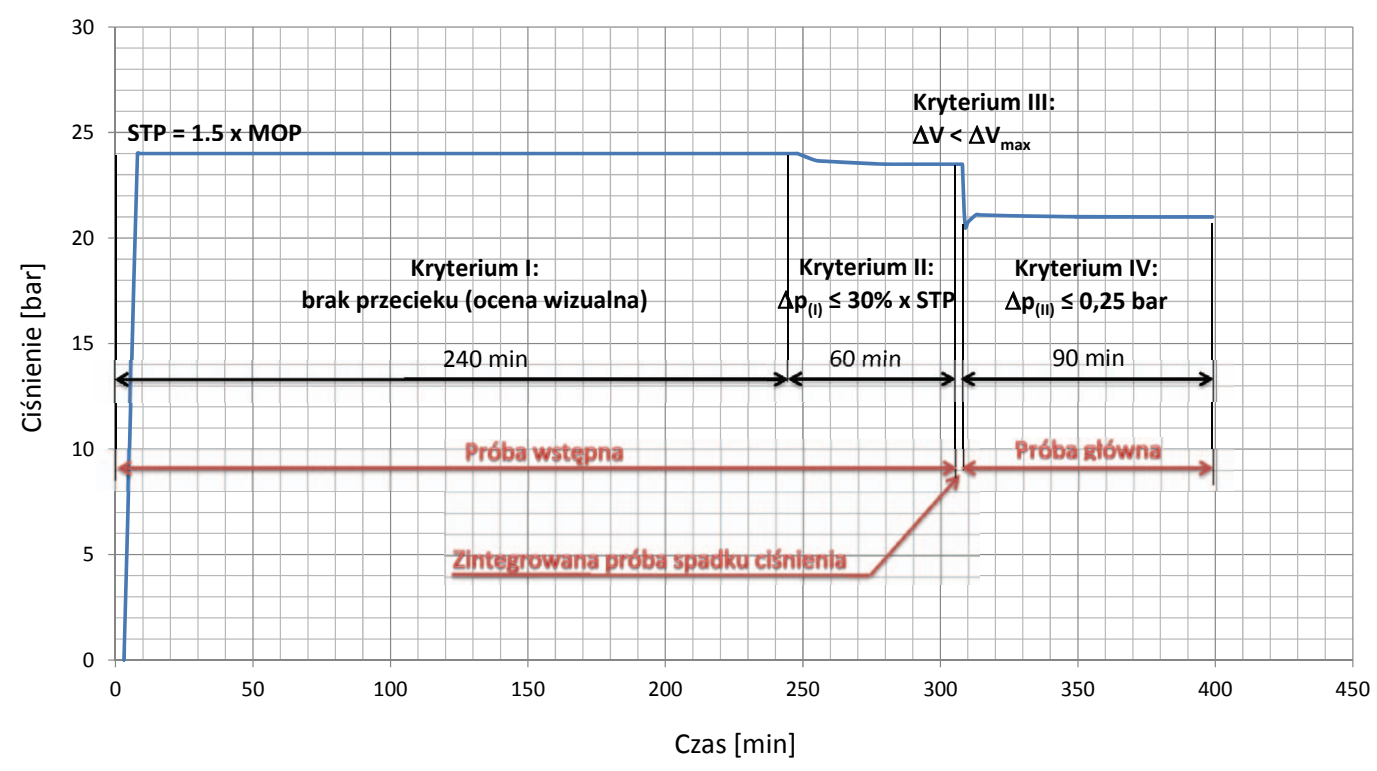

Rys. 4. Przykładowy przebieg zmian ciśnienia w czasie próby szczelności gazociągów z poliamidu PA 12

Fig. 4. An example of pressure changes during the leakage test of PA 12 polyamide gas pipelines ności gazociągów zalecane byłoby poddanie jej weryfikacji w warunkach terenowych.

Artykuł powstał na podstawie pracy statutowej pt. Modyfikacja znormalizowanej metody prowadzenia prób ciśnieniowych celem jej wykorzystania do badania szczelności gazociagów z poliamidu PA-12 - praca INiG - PIB na zlecenie MNiSW; nr zlecenia 0056/GP/2018, nr archiwalny DK-4100-0056/2018.

\section{Literatura}

Bolt A., Suligowski Z., 2007. Próby szczelności rurociągów ciśnieniowych z tworzyw po-

\section{Wnioski}

1. Przeprowadzone badania modelowe wykazały, że możliwe jest prowadzenie hydrostatycznych prób szczelności gazociągów z poliamidu PA 12 według procedury opisanej w punkcie A.27 normy PN-EN 805:2002 przy zmodyfikowanych jej parametrach.

2. Podczas próby wstępnej czas utrzymywania badanego rurociągu pod ciśnieniem przez dopompowywanie powinien być wydłużony z wartości 30 min, określonej w normie, do wartości $240 \mathrm{~min}$, tj. wyznaczonego doświadczalnie czasu niezbędnego do odpowiedniego odkształcenia rury i wynikającego ze zjawiska pełzania.

3. Zgodnie z normą PN-EN 805:2002 jednym z kryteriów próby głównej jest wzrost ciśnienia w czasie 30 min jej trwania. Podczas badań początkowo uzyskiwano wzrost ciśnienia, jednak następnie występowała jego stabilizacja i niewielki spadek. W takich przypadkach dopuszczalne było przez normę PN-EN 805:2002 wydłużenie próby głównej do 90 min i ocena próby na podstawie spadku ciśnienia po tym czasie. We wszystkich przeprowadzonych próbach konieczne było wydłużanie ich czasu do 90 min, dlatego też w zmodyfikowanej metodzie prowadzenia prób szczelności uznano, że można pominąć kryterium po 30 min i zastosować tylko kryterium odnoszące się do spadku ciśnienia po $90 \mathrm{~min}$.

4. Przeprowadzone badania na próbkach szczelnych oraz z symulowaną nieszczelnością potwierdziły, że zmodyfikowana metoda mogłaby zostać wykorzystana do badania szczelności gazociągów z poliamidu PA 12 o MOP 1,6 MPa. Przed stosowaniem opracowanej metody do badania szczel- limerowych. Instal, 7/8: 70-73.

Janson L.-E., 1996. Plastics pipes for water supply and sewage disposal. Borealis, Sven Axelsson AB/Affisch \& Reklamtryck AB, Boras.

Klupa A., 2010. Rury z materiałów kompozytowych do przesyłania paliw gazowych. Nafta-Gaz, 9: 805-809.

Kupraszewicz W., 2008. Próby szczelności rurociągów z tworzyw sztucznych. Wodociagi - Kanalizacja, 7/8: 37-39.

Mason J.F., Ponda A., Stanley M., Demicoli D., 2017. Case Study: Engineered Polyamide 12 (PA12) Pipeline Liner for Management of Sour Gas Corrosion at Elevated Temperatures. CORROSION 2017, New Orleans, Louisiana, USA.

Szewczyk P., 2017. Weryfikacja dostępnych procedur prowadzenia prób szczelności rurociągów z tworzyw sztucznych o MOP = 1,6 MPa. Praca statutowa INiG -PIB, nr zlec. 0114/ GP/2017, Archiwum Instytutu Nafty i Gazu-Państwowego Instytutu Badawczego, Kraków.

Wróblewska A., 2013. Szybka propagacja pęknięć w sieciach gazowych z rur polietylenowych. Nafta-Gaz, 10: 788-793.

\section{Akty prawne i dokumenty normatywne}

ISO 16486-6:2012 Plastics piping systems for the supply of gaseous fuels - Unplasticized polyamide (PA-U) piping systems with fusion jointing and mechanical jointing - Part 6: Code of practice for design, handling and installation.

PN-EN 12327:2013 Infrastruktura gazowa - Próby ciśnieniowe, procedury uruchamiania i unieruchamiania - Wymagania funkcjonalne.

PN-EN 805:2002 Zaopatrzenie w wodę - Wymagania dotyczące systemów zewnętrznych i ich części składowych.

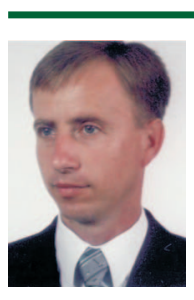

Mgr inż. Piotr SZEWCZYK

Główny specjalista inżynieryjno-techniczny; kierownik Zakładu Przesyłania i Dystrybucji Gazu Instytut Nafty i Gazu - Państwowy Instytut Badawczy ul. Lubicz $25 \mathrm{~A}$

31-503 Kraków

E-mail: piotr.szewczyk@inig.pl 